\title{
Estimation of GDD (Growing Degree Days) under Different Phenophase to Different Rice Genotypes under SRI and Traditional Methods Cultivation
}

\author{
Ravi Ranjan Sahu' ${ }^{1}$, Deepti Patel ${ }^{2}$, Dogendra Kumar Sahu ${ }^{3 *}$, Smita Balabarik ${ }^{2}$, \\ Anuj Roshan Toppo ${ }^{4}$ and Punam Lal Kerketta ${ }^{5}$
}

${ }^{1}$ Department of Agrometeorology, Indira Gandhi Krishi Visvavidhyalya, Raipur C.G., India

${ }^{2}$ Department of Vegetable Science, Indira Gandhi Krishi Visvavidhyalya, Raipur C.G., India

${ }^{3}$ Department of Soil Science and Agricultural Chemistry, SHUATS, Allahabad, U.P., India

${ }^{4}$ Department of Agronomy, Indira Gandhi Krishi Visvavidhyalya, Raipur C.G., India

${ }^{5}$ Department of Soil Science and Agricultural Chemistry, Indira Gandhi Krishi

Visvavidhyalya, Raipur C.G., India

*Corresponding author

\begin{tabular}{|c|c|}
\hline & A B S T R A C T \\
\hline & \multirow{7}{*}{$\begin{array}{l}\text { The present investigation on "Estimation of GDD (growing degree days) under different } \\
\text { phenophase to different rice genotypes under SRI and tradition methods of cultivation" } \\
\text { was conducted during Kharif season } 2007 \text { with } 32 \text { genotypes of rice at Research Farm of } \\
\text { Indira Gandhi Krishi Vishwavidyalaya, Raipur (Chhattisgarh).It is observed from the } \\
\text { investigation that the GDD method of computing in the crop duration is better method than } \\
\text { duration in days. The grain yield was highest in respect of genotype R-1124-91-2-73-1 } \\
\left(645.8 \mathrm{~g} \mathrm{~m}^{-2}\right) \text { in SRI method of cultivation which had the highest thermal use efficiency } \\
\text { (TUE) of } 0.509 \mathrm{~g} \mathrm{~m}^{-20} \text { days }{ }^{-1} \text {. The thermal use efficiency of genotypes provides information } \\
\text { on the ability of the genotypes performance under thermal stress conditions. Highest } \\
\text { number of cumulative sunshine hours of genotype R-1218-509-2-452-1, IR-64 and } \\
\text { Mahamaya were under SRI method of cultivation. Highest light use efficiency was } \\
\left.\text { observed in respect of genotype R-1124-91-2-73-1(1.962 } \mathrm{g} \mathrm{m}^{-2} \mathrm{SSH}^{-1}\right) \text { followed by } \\
\left.\text { genotype R-1217-536-1-259-1(1.638 g m} \text { g }^{-2} \mathrm{SSH}^{-1}\right) \text { in SRI method of cultivation. }\end{array}$} \\
\hline Keyworas & \\
\hline & \\
\hline $\begin{array}{l}\text { Thermal use } \\
\text { Efficiency }\end{array}$ & \\
\hline & \\
\hline Article Info & \\
\hline $\begin{array}{l}\text { Accepted: } \\
\text { 10 November } 2018 \\
\text { Available Online: } \\
10 \text { December } 2018\end{array}$ & \\
\hline
\end{tabular}

\section{Introduction}

In general, rice is grown under diverse environmental conditions from a wide range of latitude and altitudes. It is also grown under all the 3 rice growing environments like uplands, lowlands and midlands. The major climatic factors affecting growth and yield include solar radiation, temperature and rainfall. The rainfall is particularly important in rainfed rice cultivation. When compared to other crops, the water requirement for rice crop is very high. It is often believed that standing water of at least $5 \mathrm{~cm}$ depth is needed for rice crop right from transplanting to flowering and grain filling stages. With increasing water crisis in many parts of the world including India, newer technologies are being developed with minimum water use for rice cultivation. 
The system of rice intensification called, in short, SRI is one of such alternatives. The system is capable of saving irrigation water up to 50 to 60 per cent as compared to traditional practices and also increases yield. The SRI was first developed by Herri de Lunlqnie in 1980 in Madagascar and hence it is also known as "Madagascar method" by people of other countries. It is a technique of increasing productivity by changing management of plant, soil water and nutrients; it involves single young seedlings planted widely on aerated soil and most importantly keeping rice field moist but not flooded.

It is hypothesized that all the genotypes may not perform well under SRI method and only a few genotypes are suitable for SRI method of cultivation. The reason for such hypothesis is that the changes in micro-climate due to changes in crop geometry and also due to field hydrological conditions are responsible for the difference in genotype $\mathrm{x}$ environment interaction. The environment means that it may either be thermal or light or radiation regimes. In view of the above hypothesis, the experiment was conducted with 32 rice genotypes cultivated under both SRI and traditional methods of rice cultivation with the objective to evaluate rice genotypes suitable under SRI and Traditional Methods of cultivation.

\section{Materials and Methods}

The experiment was conducted at research cum instructional farm, Indira Gandhi Krishi Vishwavidyalaya, Raipur situated in SouthEastern part of Chhattisgarh at latitudes, longitudes and altitude of $21.16^{\circ} \mathrm{N}, 81.36^{\circ} \mathrm{E}$ and $289.5 \mathrm{~m}$ above mean sea level, respectively. In the experiment 32 genotype verities of Rice were evaluated for the work out GDD under SRI and Traditional method. the light and radiation regimes were favorable for rice crop. Regarding the temperature, the maximum temperature was always above 25 ${ }^{0} \mathrm{C}$ indicating that it was always above the lower limit of cardinal temperature. Hence, the maximum temperature was favorable to rice crop. In case of minimum temperature it was also above $15{ }^{0} \mathrm{C}$ during the entire crop growth period. In fact, lower night temperatures $(<15$ $\left.{ }^{0} \mathrm{C}\right)$ at the time of an thesis results in sterility but during the study period the minimum temperature was favorable for rice crop. The weekly meteorological parameters recorded at agro-meteorological observatory, IGKV, Raipur.

\section{Results and Discussion}

\section{Crop duration and growing degree days}

The duration required from sowing to $50 \%$ flowering in respect of all the genotypes under both the methods of cultivation were recorded based on the GDD required for each

genotypes and are shown in table 1. It is clearly observed that the crop duration under SRI method of cultivation difference between SRI method and traditional method varied from 1 day to 18 days in respect of different genotypes.

This is because, in the SRI method of cultivation the age of seedling was 12 days at the time of transplanting in traditional method of cultivation the age of seedling was 21 days. The difference of 9 days continued till $50 \%$ flowering with slight genotypic variation. The only advantage in the SRI method is the nursery can be raised late by and 20 days and plantation can be done during the optimum time of plantation.

Regarding the GDD the same trend was observed in respect of the growing degree days. The required GDD in the traditional method of cultivation was slightly higher in all the genotypes as the duration was longer 
except in a couple of genotypes as the nursery shown earlier in when the temperature is higher for traditional method of rice cultivation. The differences in GDD are not as much as the difference in duration. This is a good indication that the GDD method of computing the duration is better method than counting the days.
The result was in accordance of the findings of Chopra and Nisha (2004) that with decreasing in calendar days and GDD, the vegetative and generative phase was reduced, Khan et al., (2006) reported highest GDD for vegetative phase and lowest GDD for reaching the reproductive and ripening phase.

Table.1 Computation of crop duration up to $50 \%$ flowering and corresponding GDD of rice genotypes between SRI and Traditional methods

\begin{tabular}{|c|c|c|c|c|c|}
\hline \multirow[b]{2}{*}{ S. No } & \multirow[t]{2}{*}{ GENOTYPES } & Date & SRI & Date & TM \\
\hline & & $50 \%$ Flowering & $\operatorname{GDD}\left({ }^{\circ} \mathrm{C}\right)$ & $50 \%$ Flowering & $\operatorname{GDD}\left({ }^{\circ} \mathrm{C}\right)$ \\
\hline 1 & Poornima & 30-Sep & 1085.2 & 15-Sep & 1064.5 \\
\hline 2 & Danteshwari & 25-Sep & 1159.5 & 13-Sep & 1029.4 \\
\hline 3 & R-1033-968-2-1 & 26-Sep & 1122.0 & 16-Sep & 1082.1 \\
\hline 4 & R-1099-2596-1-1 & 27-Sep & 1140.7 & 20-Sep & 1150.5 \\
\hline 5 & R-1013-2297-1-1 & 24-Sep & 1103.4 & 27-Sep & 1274.8 \\
\hline 6 & R-1182-167-2-1 & 28-Sep & 1177.9 & 26-Sep & 1256 \\
\hline 7 & Shamleshwari & 25-Sep & 1122.0 & 25-Sep & 1237.4 \\
\hline 8 & R-1037-649-1-1 & 26-Sep & 1140.7 & 25-Sep & 1237.4 \\
\hline 9 & R-1162-1667-1-1 & 3-Oct & 1269.3 & 25-Sep & 1237.4 \\
\hline 10 & R-1102-2795-3-1 & 7-Oct & 1339.4 & 27-Sep & 1274.8 \\
\hline 11 & $\mathrm{R}-1217-536-1-259-1$ & 26-Sep & 1140.7 & 25-Sep & 1237.4 \\
\hline 12 & Chandrahsini & 28-Sep & 1177.9 & 25-Sep & 1237.4 \\
\hline 13 & MTU-1010 & 2-Oct & 1250.9 & 25-Sep & 1237.4 \\
\hline 14 & R-979-67-2-44-1 & 6-Oct & 1322.5 & 28-Sep & 1293.2 \\
\hline 15 & RDG-1 & 30-Sep & 1213.9 & 20-Sep & 1150.5 \\
\hline 16 & IRH-5 & 26-Sep & 1140.7 & 28-Sep & 1293.2 \\
\hline 17 & R-1248-1489-2-822-1 & 3-Oct & 1269.3 & 30-Sep & 1329.3 \\
\hline 18 & IR-36 & 2-Oct & 1250.9 & 24-Sep & 1218.8 \\
\hline 19 & R-1072-360-1-1 & 8-Oct & 1356.9 & 27-Sep & 1274.8 \\
\hline 20 & R-1218-509-2-452-1 & 9-Oct & 1374.3 & 28-Sep & 1293.2 \\
\hline 21 & IR-64 & $5-O c t$ & 1304.8 & 26-Sep & 1256 \\
\hline 22 & $\mathrm{R}-548-89-6$ & 9-Oct & 1374.3 & 29-Sep & 1311.6 \\
\hline 23 & R-703-1-52-1-1 & 6-Oct & 1322.5 & 26-Sep & 1256 \\
\hline 24 & R-1124-91-2-73-1 & 3-Oct & 1269.3 & 23-Sep & 1200.6 \\
\hline 25 & R-1250-1557-895-1 & 7-Oct & 1339.4 & 28-Sep & 1293.2 \\
\hline 26 & Madhuri & 7-Oct & 1339.4 & 24-Sep & 1218.8 \\
\hline 27 & R-1033-2559-1-1 & 4-Oct & 1286.9 & 1-Oct & 1348.2 \\
\hline 28 & Karma Masuri & $5-\mathrm{Oct}$ & 1304.8 & 29-Sep & 1311.6 \\
\hline 29 & Indira Sugandhit & 5-Oct & 1304.8 & 30-Sep & 1329.3 \\
\hline 30 & R-1055-1629-4-1 & 8-Oct & 1356.9 & 5-Oct & 1420.1 \\
\hline 31 & Mahamaya & 9-Oct & 1374.9 & 4-Oct & 1402.3 \\
\hline 32 & Kranti & 6-Oct & 1322.5 & 4-Oct & 1402.3 \\
\hline
\end{tabular}


Table.2 Growing degree day andthermal use efficiency in respect of yield production of different genotypes under SRI and traditional method of sowing

\begin{tabular}{|c|c|c|c|c|c|c|c|}
\hline \multirow[t]{2}{*}{ S. No. } & \multirow[t]{2}{*}{ Genotypes } & \multicolumn{2}{|c|}{ GDD $\left({ }^{0} \mathrm{C}\right)$} & \multicolumn{2}{|c|}{ Yield $(\mathrm{gm} / \mathrm{m}-2)$} & \multicolumn{2}{|c|}{ TUE $\left(\right.$ gm m- $\left.{ }^{2} /{ }^{\circ} \mathrm{C} \mathrm{GDD}\right)$} \\
\hline & & SRI & TM & SRI & TM & SRI & TM \\
\hline 1 & Poornima & 1085.2 & 1064.5 & 250 & 229.2 & 0.23 & 0.215 \\
\hline 2 & Danteshwari & 1159.5 & 1029.4 & 229.2 & 235.4 & 0.198 & 0.229 \\
\hline 3 & R-1033-968-2-1 & 1122 & 1082.1 & 491.7 & 354.2 & 0.438 & 0.327 \\
\hline 4 & R-1099-2596-1-1 & 1140.7 & 1150.5 & 354.2 & 281.3 & 0.31 & 0.244 \\
\hline 5 & R-1013-2297-1-1 & 1103.4 & 1274.8 & 400 & 385.4 & 0.363 & 0.302 \\
\hline 6 & R-1182-167-2-1 & 1177.9 & 1256 & 437.5 & 312.5 & 0.371 & 0.249 \\
\hline 7 & Shamleshwari & 1122 & 1237.4 & 250 & 239.6 & 0.223 & 0.194 \\
\hline 8 & R-1037-649-1-1 & 1140.7 & 1237.4 & 395.8 & 302.1 & 0.347 & 0.244 \\
\hline 9 & R-1162-1667-1-1 & 1269.3 & 1237.4 & 437.5 & 375 & 0.345 & 0.303 \\
\hline 10 & R-1102-2795-3-1 & 1339.4 & 1274.8 & 433.3 & 427.1 & 0.324 & 0.335 \\
\hline 11 & $\begin{array}{l}\text { R-1217-536-1-259- } \\
1\end{array}$ & 1140.7 & 1237.4 & 466.7 & 406.3 & 0.409 & 0.328 \\
\hline 12 & Chandrahsini & 1177.9 & 1237.4 & 270.8 & 302.1 & 0.23 & 0.244 \\
\hline 13 & MTU-1010 & 1250.9 & 1237.4 & 345.8 & 395.8 & 0.276 & 0.32 \\
\hline 14 & R-979-67-2-44-1 & 1322.5 & 1293.2 & 520.8 & 562.5 & 0.394 & 0.435 \\
\hline 15 & RDG-1 & 1213.9 & 1150.5 & 333.3 & 250 & 0.275 & 0.217 \\
\hline 16 & IRH-5 & 1122 & 1293.2 & 395.8 & 437.5 & 0.353 & 0.338 \\
\hline 17 & $\begin{array}{l}\text { R-1248-1489-2- } \\
822-1\end{array}$ & 1269.3 & 1329.3 & 562.5 & 437.5 & 0.443 & 0.329 \\
\hline 18 & IR-36 & 1250.9 & 1218.8 & 258.3 & 214.6 & 0.207 & 0.176 \\
\hline 19 & R-1072-360-1-1 & 1356.9 & 1274.8 & 437.5 & 312.5 & 0.322 & 0.245 \\
\hline 20 & $\begin{array}{l}\text { R-1218-509-2-452- } \\
1\end{array}$ & 1374.3 & 1293.2 & 520.8 & 479.2 & 0.379 & 0.371 \\
\hline 21 & IR-64 & 1304.8 & 1256 & 437.5 & 406.3 & 0.335 & 0.323 \\
\hline 22 & R-548-89-6 & 1374.3 & 1311.6 & 466.7 & 395.8 & 0.34 & 0.302 \\
\hline 23 & R-703-1-52-1-1 & 1322.5 & 1256 & 458.3 & 343.8 & 0.347 & 0.274 \\
\hline 24 & R-1124-91-2-73-1 & 1269.3 & 1200.6 & 645.8 & 385.4 & 0.509 & 0.321 \\
\hline 25 & $\begin{array}{l}\text { R-1250-1557-895- } \\
1\end{array}$ & 1339.4 & 1293.2 & 458.3 & 375 & 0.342 & 0.29 \\
\hline 26 & Madhuri & 1339.4 & 1218.8 & 291.7 & 166.7 & 0.218 & 0.137 \\
\hline 27 & R-1033-2559-1-1 & 1286.9 & 1348.2 & 354.2 & 406.3 & 0.275 & 0.301 \\
\hline 28 & Karma Masuri & 1304.8 & 1311.6 & 322.9 & 520.8 & 0.247 & 0.397 \\
\hline 29 & Indira Sugandhit & 1304.8 & 1329.3 & 125 & 270.8 & 0.096 & 0.204 \\
\hline 30 & R-1055-1629-4-1 & 1356.9 & 1420.1 & 500 & 406.3 & 0.368 & 0.286 \\
\hline 31 & Mahamaya & 1374.9 & 1402.3 & 458.3 & 447.9 & 0.333 & 0.319 \\
\hline 32 & Kranti & 1322.5 & 1402.3 & 375 & 343.8 & 0.284 & 0.245 \\
\hline
\end{tabular}


Growing degree days and thermal use efficiency

As mentioned the earlier, the growing degree days of 32 genotypes varied from 1085 to 1374 under SRI methods and 1064 to 1420 in traditional method. In the other words the thermal requirements of different genotypes vary differently. When the grain yield is expressed in terms of GDD it is known as thermal use efficiency. The GDD grains yield and thermal use efficiency of 32 genotypes under both SRI and traditional methods of rice cultivation are shown in table 2.

The grain yield was the highest in respect of genotype R-1124-91-2-73-1inSRI method of cultivation while the highest grain yield in traditional method of cultivation was in respect of genotype R-979-67-2-44-1 and because of this the thermal use efficiency also varied in respect of different genotypes under both the methods of cultivation. Highest thermal use efficiency of $\left(0.509 \mathrm{~g} \mathrm{~m}^{-20}\right.$ days $\left.^{-1}\right)$ was observed in respect of genotype R-112491-2-73-1 in SRI method of cultivation, while in traditional method of cultivation the highest thermal use efficiency $\left(0.435 \mathrm{~g} \mathrm{~m}^{-}\right.$ ${ }^{20}$ days $^{-1}$ )was observed in respect of genotype R-979-67-2-44-1. The thermal use efficiency of genotypes provides information on of the ability of the genotypes performance stress under thermal conditions. Similar results were also observed by Yoshida and Parao (1976) found highest effect of radiation maturity and vegetative phase, Murta (1976), Doorenbos (1977) for radiation, Triphati et al., (2000) and Al Khaffaf et al., (2003).

The summary and conclusions of the study are as follows:

\section{Crop duration and growing degree days}

In the case of SRI method of rice cultivation the age of seedling was 12 days at time of transplanting whereas in traditional method of cultivation the age of seedling was 21 days. From the recording of GDD, the same trend has been observed. In fact the growing degree days required in the traditional method of cultivation was slightly lower in all the genotypes as the duration was lower. The difference in GDD was not as much as the difference in duration. This seems to be a good indication that the GDD method of computing the duration is better method than counting the days. The difference in GDD is not as much as the duration showed. This infers that the GDD method of computing the duration is better than counting the days as duration.

\section{Growing Degree Days (GDD) and Thermal Use Efficiency (TUE)}

Examine the growing degree days of 32 genotypes it was found that GDD varied from 1085 to 1374 under SRI method and 1064 to 1420 in traditional method in different genotypes. In respect to TUE, it varied from 0.096 to $0.509 \mathrm{~g} \mathrm{~m}^{-20}$ days $^{-1}$ under SRI method and 0.204 to $0.435 \mathrm{~g} \mathrm{~m}^{-20}$ days $^{-1}$ in traditional method. The grain yield was highest in respect of genotypes R-1124-91-2-73-1under SRI method of rice cultivation, while highest grain yield in traditional method of cultivation was in respect of genotype R-979-67-2-441and because of this the thermal use efficiency also varied in respect of different genotypes under the methods of cultivation.

\section{Acknowledgement}

Authors are sincerely thankful to Dr. A.S.R.A.S. Sastri, Associate Prof., Department of Agrometeorology, Dr. A. P. Singh, Senior Scientist, Department of Agronomy,Dr. A. K. Sarawni, Scientist (Rice), Department of Plant Breeding and Genetic, and Dr. (Smt.) G. Chandrakar, Senior Scientist, Department of Statistic, Dr. 
S.R.Patel, Professor Department of Agrometeorology, Indira Gandhi Krishi Vishwavidyalaya, Raipur.

\section{References}

Al-Khaffaf, A., Merza, T. K. and Hajary, A. O., 2003. Effects of temperatures and light accumulations on some vegetative growth characteristics and dry weight at flowering and harvest of three rice cultivars (Oryza sativa L.). Journal of Natural and Applied Sciences.7 (1): 113.

Chopra, N. K. and Chopra, N. 2004. Influence of transplanting dates on heat-unit requirement of different phenological stages and subsequently yield and quality of scented rice (Oryza sativa) seed. Indian J. of Agri. Sciences. 74 (8): 415-419.

Doornbos, J. and Prvitt, W.U. 1977. Crop water requirement FAO irrigation and drainage. Paper No. 24, FAO, Rome. pp 21-63.

Khan, S. A., Mainty, G. C. and Das, L. 2005. Prediction of grain yield of kharif rice based on thermal, eliothermal and photothermal units prevailing during different phases of growth. Environment and Ecology. 23 (3): 545-552.

Khan, S. A., Maity, G. C. and Das, L. 2006. Phasic development models of kharif rice based on heat unit. Journal-ofInteracademicia. 10 (1): 60-64.

Murta, Y. 1976. Productivity of rice in different climatic regions of Japan. University of Tokyo press, Tokyo. pp 77-79

Tripathi, P., Singh, A. K., and Mishra, S. R. (2000). Study of temperature modification by rice crop and its impact under rice-wheat cropping system. International journal of agriculture Science 1: 11-15.

Yoshida, S. and Parao, P.T. 1976. Climatic influence on yield component of lowland rice in the tropics. In Climate and Rice, International Rice Research Institute, Las Bonos, Laguna. pp.471494.

Yoshida, S. 1981. Fundamental of rice crop science, IRRI, Philippines.

\section{How to cite this article:}

Ravi Ranjan Sahu, Deepti Patel, Dogendra Kumar Sahu, Smita Balabarik, Anuj Roshan Toppo and Punam Lal Kerketta. 2018. Estimation of GDD (Growing Degree Days) under Different Phenophase to Different Rice Genotypes under SRI and Traditional Methods Cultivation. Int.J.Curr.Microbiol.App.Sci. 7(12): 1171-1176. doi: https://doi.org/10.20546/ijcmas.2018.712.145 